\title{
MESOSCALE CONVECTIVE COMPLEXES IN RIO GRANDE DO SUL BETWEEN OCTOBER AND DECEMBER OF 2003 AND ASSOCIATED PRECIPITATION
}

\author{
DENILSON RIBEIRO VIANA ${ }^{1,2}$, FRANCISCO ELISEU AQUINO ${ }^{2}$, RICARDO BURGOBRAGA ${ }^{2}$ AND \\ NELSON JESUS FERREIRA ${ }^{1}$
}

\author{
${ }^{1}$ Instituto Nacional de Pesquisas Espaciais \\ Centro de Previsão do Tempo e Estudos Climáticos (CPTEC/ INPE) \\ ${ }^{2}$ Universidade Federal do Rio Grande do Sul \\ Centro Polar e Climático (CPC/IGEO/UFRGS) \\ NOTOS - Laboratório de Climatologia \\ ribeiro.denilson@gmail.com, francisco.aquino@ufrgs.br, \\ burgobraga@gmail.com,nelson.ferreira@cptec.inpe.br
}

Received December 2007 - Accepted May 2009

\begin{abstract}
This study investigates the occurrences of Mesoscale Convective Complexes (MCC) and the associated precipitation in the southernmost Brazilian state, Rio Grande do Sul (RS), from October to December of 2003. The identification of MCC events was done using ForTraCC. The MCC precipitation was based on the daily data of 31 local weather stations. Twenty-two MCC events were identified over RS during the three month study period, and this total, seven events occurred in October, seven in November and eight in December. Results point to an MCC associated precipitation average of $119 \mathrm{~mm}$ in October, $90 \mathrm{~mm}$ in November and $152 \mathrm{~mm}$ in December. The percentages for MCC precipitation averages, for the period, were $64 \%$ in October, $65 \%$ in November and $61 \%$ in December. The average accumulated volume of MCC precipitation for the three months was $361 \mathrm{~mm}(63 \%)$. This confirms that MCC events contributed significantly to the precipitation totals in RS, and were responsible for almost two thirds of the precipitation in RS, for the period. Keywords: Mesoscale Convective Complexes, precipitation anomalies, Rio Grande do Sul

RESUMO: COMPLEXOS CONVECTIVOS DE MESOESCALA NO RIO GRANDE DO SUL ENTRE OUTUBRO E DEZEMBRO DE 2003 E QUANTIFICAÇÃO DA PRECIPITAÇÃO ASSOCIADA

Este estudo investiga a ocorrência de Complexos Convectivos de Mesoescala (CCM) e a precipitação associada aos eventos no Estado do Rio Grande do Sul (RS), entre outubro e dezembro de 2003. A identificação dos CCM foi feita através do aplicativo ForTraCC e, para quantificação dos totais de precipitação oriundos de CCM, foram utilizados dados diários de 31 estações meteorológicas. Durante o período de estudo, foram identificados 22 eventos de CCM sobre o RS. Deste total, sete ocorreram em outubro, sete em novembro e oito em dezembro. Os dados analisados apontam para um volume médio de precipitação de CCM no RS de $119 \mathrm{~mm}$ em outubro, $90 \mathrm{~mm}$ em novembro e $152 \mathrm{~mm}$ em dezembro. Do total de precipitação registrado para o período, o percentual oriundo de CCM ficou em $64 \%$ no mês de outubro, $65 \%$ em novembro e $61 \%$ em dezembro. O volume médio de precipitação de CCM acumulado no trimestre ficou em $361 \mathrm{~mm}$, uma participação percentual de $63 \%$, confirmando que os CCM contribuíram significativamente para a precipitação no Estado e foram responsáveis por quase dois terços da chuva observada no RS no período.
\end{abstract}

Palavras-chave: Complexos Convectivos de Mesoescala, Anomalias de Precipitação, Rio Grande do Sul 


\section{INTRODUCTION}

October, November and December of 2003 registered precipitation above the historic average across nearly the entire southern region of Brazil (Climanálise 2003a, 2003b, 2003c). For October, slightly positive deviations were identified for the northeastern sector of Rio Grande do Sul (RS), western Santa Catarina (SC) and Paraná (PR), with anomalies exceeding 50 $\mathrm{mm}$, and, in November, above average precipitation occurred across nearly the entire region. The most significant accumulation $(>100 \mathrm{~mm}$ ) occurred in the southern and northeastern sectors of $\mathrm{RS}$, in the north central and western sectors of SC, and in the south and west of PR. December had the highest precipitation totals during the three-month period for the region, with positive precipitation deviations above $200 \mathrm{~mm}$ in the north and northwest sectors of RS, mid-west of SC and south of PR.

Bulletins of Climanálise (2003a, 2003b, 2003c) indicate that the occurrence of frontal systems and Mesoscale Convective Complexes (MCC) were responsible for the excessive volume of precipitation observed for the region during this period. In October, according to Climanálise (2003a), seven frontal systems were associated with cyclogenesis in the region and were responsible for the precipitation. In November, besides the cyclogenesis, the intensification of the Low Level Jet (LLJ) and the increase of convective activity in southern Brazil, Uruguay, northeastern Argentina and Paraguay promoted MCC development, and were responsible for the intense rains and strong winds in many localities (Climanálise, 2003b). Nine frontal systems associated with MCC events were observed in December, resulting in above average precipitation in the southern region. These MCC events were observed on December 8, 13, 19 and 20 (Climanálise, 2003c).

\subsection{A brief review of $\mathrm{MCC}$ events occurring in South America}

Satyamurty et al. (1998) described the main air masses and atmospheric systems, at lower levels $(850 \mathrm{hPa})$ as well as upper levels (200 hPa), active over South America (SA) in the summer. These authors also indicate that besides the influence of extratropical anticyclones, southern Brazil is also significantly influenced by MCC events. They also observe that the northwest sector of RS is prone to summer MCC occurrences. Severo and Gan (2004) show higher precipitation values in spring, summer and fall for the north and northwestern sectors of RS. According to Velasco and Fritsch (1987), this precipitation distribution suggests that MCC events are one of the mechanisms responsible for the high rainfall for the southern region.

MCCs are characterized as clusters of individual cells, covered by an extensive cirrus (Ci) layer, originating from the tops of mature cumulonimbus $(\mathrm{Cb})$ clouds, with a quasi-circular form and rapid development, lasting at least $6 \mathrm{~h}$. (Maddox, 1980; Maddox, 1983; Silva Dias, 1987; Velasco and Fritsch, 1987). In SA, MCC events are observed leeward of the Andes Mountains, between $25^{\circ} \mathrm{S}$ and $40^{\circ} \mathrm{S}$, which includes the northern portion of Argentina, Bolivia, southern Paraguay and frequently reaching the southern and southeastern regions of Brazil (Scolar and Silva Dias, 1982; Guedes and Silva Dias, 1984; Velasco and Fritsch, 1987). These systems occur predominately in the warm seasons of the year (summer, spring and fall) and produce a great variety of significant convective phenomena, such as tornados, hail storms, strong wind gusts, floods and intense electric storms (Maddox, 1980; Maddox, 1983).

The first storm cells, preceding MCCs formation, develop during the early evening and then make the transition to a larger, well organized system, after late evening. Most MCCs reach their maximum size after midnight, persisting until the next morning (Maddox, 1980; Velasco and Fritsch, 1987). For SA, MCCs show a "double peak" in build up time of the first storms, suggesting two different mechanisms possibly initiating the convection: the first is related to the diurnal heating cycle and the second is linked to the night-time convergence of the Paraná River Valley, enhanced by the katabatic winds from the Andes Mountains and LLJ, both reaching the maximum velocity after midnight (Velasco and Fritsch, 1987).

The mean duration for MCCs varies from $10 \mathrm{~h}$ to $20 \mathrm{~h}$ (Silva Dias, 1987). Machado et al. (1994) found that convective systems over SA, across the mid-latitudes and in summer, have a mean radius of $240 \mathrm{~km}$ and an average duration of $15 \mathrm{~h}$. According to Silva Dias (1996), some systems initially classified as MCCs can turn into vortices, such as described by Bonatti and Rao (1987), where the system presents itself as an MCC during the first six hours and then assumes the form of an inverted comma cloud, characteristic of a cyclonic vortex, persisting $48 \mathrm{~h}$ more.

The paths of most MCCs are from east to southeast, frequently reaching the southern Brazilian states, but some take a northeastern track into the mid-western and south-eastern regions of Brazil. Figueiredo and Scolar (1996) analyzed 25 MCCs and concluded that $70 \%$ of the systems moved to the east and southeast, reaching RS and SC. The remaining 30\% progressed to the northeast and north, reaching the southeast of Brazil, as also observed by Guedes (1985). Velasco and Fritsch (1987) show greater MCC event variability, with a more zonal trend (from west to east) in spring and the beginning of fall, and more meridional (from south to north) in summer. Guedes et. al (1994) evaluated the paths of $>6$ hour duration convective systems over SA, between July 19, 1987 and June 19, 1988. This latter study found that these systems move from the southeast to the northeast, over the southern and south-eastern regions of 
Brazil. Machado et al. (1998) state that the paths of SA midlatitude convective systems, in summer and fall, are similar to those observed by Velasco and Fristch (1987), that demonstrated a more zonal trend for MCC paths, in spring and early autumn, and more meridional in summer.

The LLJ is responsible for the low latitude heat and humidity transport from the tropics, representing a main factor for MCC formation and development. Marengo et al. (2004) propose that the LLJ is a primary characteristic of atmospheric circulation over SA during summer, responsible for the meridional transport of humidity at low levels from the tropics. Although LLJs can occur at any time of year, bringing a warm humid stream of air from the Amazon to southern Brazil and northern Argentina, they are most frequent in summer when the most intense phase is after midnight. Paegle (1987) and Torres and Nicollini (2002) analyzed the relationship between the LLJ and convective systems over SA; they showed that the jets, east of the Andes Mountains, produced a favorable environment to organize deep convection. Nogués-Peagle and Berbery (2000) observed an extensive area of convective development during spring and summer, predominantly at night. This convective phenomenon is capable of systematically altering the basic precipitation pattern of the South American continent.

Corrêa et al. (2007) found that the LLJ is a transport mechanism for water vapor directly from the Atlantic Ocean to $\mathrm{SA}$, which is responsible for conserving a great deal of MCC convection. These authors suggest that LLJs, when considered independently of other factors, have the capacity of generating baroclinic instabilities, building convective systems such as MCC events, which particularly present a trend of night-cycle events for RS.

Seluchi and Marengo (2000) investigated the importance of air mass transport for both precipitation and temperature. During summer, the Chaco Low intensifies, due to the positive balance of solar radiation, favoring the transport of tropical air to the south. This produces convective activity fueled with humidity from the region. After comparing days with and days without MCCs, Tuker and Zentmire (1999) asserted that the relative humidity at $500 \mathrm{hPa}$ was significantly higher during MCC days. Mean temperatures of the MCC and non-MCC cases differ by $<1^{\circ} \mathrm{C}$ at $500 \mathrm{hPa}$. The associated differences in relative humidity fields are mainly caused by the atmospheric moisture content at this level. Conversely, at $700 \mathrm{hPa}$, the relative humidity was lower on MCC days, with temperatures more than $1{ }^{\circ} \mathrm{C}$ warmer for the MCC than non-MCC cases.

Corfidi et al. (1996) established that MCC propagation is directly proportional and correlated to the velocity and direction of the LLJ, obtaining correlation coefficients of 0.78 and 0.80 , respectively. Of the 133 systems studied, 99 were MCC events, showing a significant tendency for MCC propagation in the same direction as the LLJ. Duquia and Silva Dias (1994) confirmed that the generation area for MCCs is to the northeast of the Maximum Velocity Center (MVC), at high levels. Case studies, such as Scolar and Figueiredo (1990) also confirm this large-scale conditioning, and concluded that such events were formed to the east of low pressure centers and in areas dominated by low-level moisture convergence. The generation area for these systems is best described at $850 \mathrm{hPa}$ : closed advection cells, strong humidity convergence and the LLJ in the northerly flow, with a velocity of approximately $15 \mathrm{~m} \mathrm{~s}^{-2}$. These storms initially develop in areas of low-level warm air advection and moisture convergence.

Rocha (1992) performed model sensitivity studies showing that MCC evolution is symbiotically linked to latent heat release of convective processes, concluding that the system rapidly falls apart without this energy source. In both simulation studies (Rocha, 1992) and observational studies (Cotton et al., 1989), the gradual formation of cyclonic vorticity centers were observed at low and mid levels. These are probably responsible for the quasi-circular shape of MCCs. Similarly, there is a diverging anticyclonic vorticity center, directly above the MCCs.

Various studies were produced after Maddox (1980; 1983 ) regarding the precipitation produced by MCCs. Studying 74 MCCs from 1982 and 1983, Fritsch et al. (1986) observed that these events contributed from 20 to $50 \%$ of the annual precipitation totals for the Great Plains of the USA, showing that during June and August, the precipitation was dominated by MCCs. McAnelly and Cotton (1989) analyzed seven years of June to August MCC events, between 1977 and 1983, and concluded that in 122 cases analyzed, MCCs contributed $45 \%$ to the total June to August precipitation. Ashley et al. (2003) showed that during the warm season, significant portions of the Great Plains receive, on average, between $8 \%$ and $18 \%$ of their total precipitation from MCC rainfall. However, there is large yearly and even monthly variability in the location and frequency of MCC events that lead to highly variable precipitation contributions. The study encompasses 527 events over 15 years, an average of 35 MCCs per year.

Several investigations have been done in other regions to identify the occurrence of MCC events. Laing et al. (1999) analyzed June to September of 1987 and found that MCCs accounted for $22 \%$ of the average precipitation in the Sahel. Laing and Fritsch (1993), employing the MCC classification proposed by Maddox (1980), asserted that the systems observed in the Indian monsoon region share characteristics with MCCs over the Americas (e.g. night-time systems, developing over the continent, with an average life cycle of $9 \mathrm{~h}$ ). The high precipitation frequency indicates that MCCs are fundamental components of the Indian monsoon hydrological cycle. MCCs have also been documented in other regions, such as the 
western Pacific (Miller and Fritsch, 1991), showing similar characteristics to those of North American MCC events.

Scaglioni and Gomes (2005) found that one MCC, on February 3, 2003, was responsible for impressive precipitation values in RS. According to the authors, this MCC reached the southwestern sector of RS and resulted in high daily accumulated precipitation at three local municipalities: Santana do Livramento (149.9 mm), Bagé (67.2 mm) and Santa Vitória do Palmar $(24.5 \mathrm{~mm})$.

Based on the previous research, regarding MCCs over SA, it is apparent that RS is frequently in the path of MCCs. Abdoulaev et al. (1996) showed that convective systems cause a minimum of 13 natural hazards every year just in RS, and some of these disasters were directly related to MCCs. The research presented in this article focuses on identifying MCCs that occurred during October to December of 2003, in RS, to quantify the associated MCC precipitation and the percentage of MCC rainfall, for the period.

\section{DATA}

\subsection{Satellite imagery}

GOES-12 and Meteosat (infrared channel) imagery, enhanced according to Cloud Top Temperature (CTT), was employed to visualize and locate MCC events and their area of influence. Along with the diagnostic files, the DSA-INPE team offered this imagery in JPEG, comprising the whole study period (October to December of 2003), with a time interval of one-half hour. In all, around 9,700 images of the southern region of Brazil and SA allowed for visual identification and the observation of MCC event evolution, over RS.

\subsection{Precipitation data}

To evaluate precipitation in RS, data were examined from 31 weather stations. These weather stations are maintained by Fundação Estadual de Pesquisa Agropecuária do Rio Grande do Sul (FEPAGRO) and from the $8^{\circ}$ Distrito de Meteorologia- $8^{\circ}$ DISME, a regional division of Instituto Nacional de Meteorologia (INMET). Figure 1 illustrates the spatial distribution of the weather stations and Table 1 presents geographic references for each site.

Monthly precipitation climate normals (1971-2000) were calculated from monthly accumulated values for each weather station. The climate normal (normal) corresponds to a standard 30-year observation period, recommended by the World Meteorological Organization (WMO). The data were distributed by INMET and FEPAGRO. The regional pondering method, proposed by Tubelis and Nascimento (1980), was used to fill in any data gaps, shown as:

$$
y=\frac{1}{3} \times\left[\frac{x 1}{x m 1}+\frac{x 2}{x m 2}+\frac{x 3}{x m 3}\right] \times y m
$$

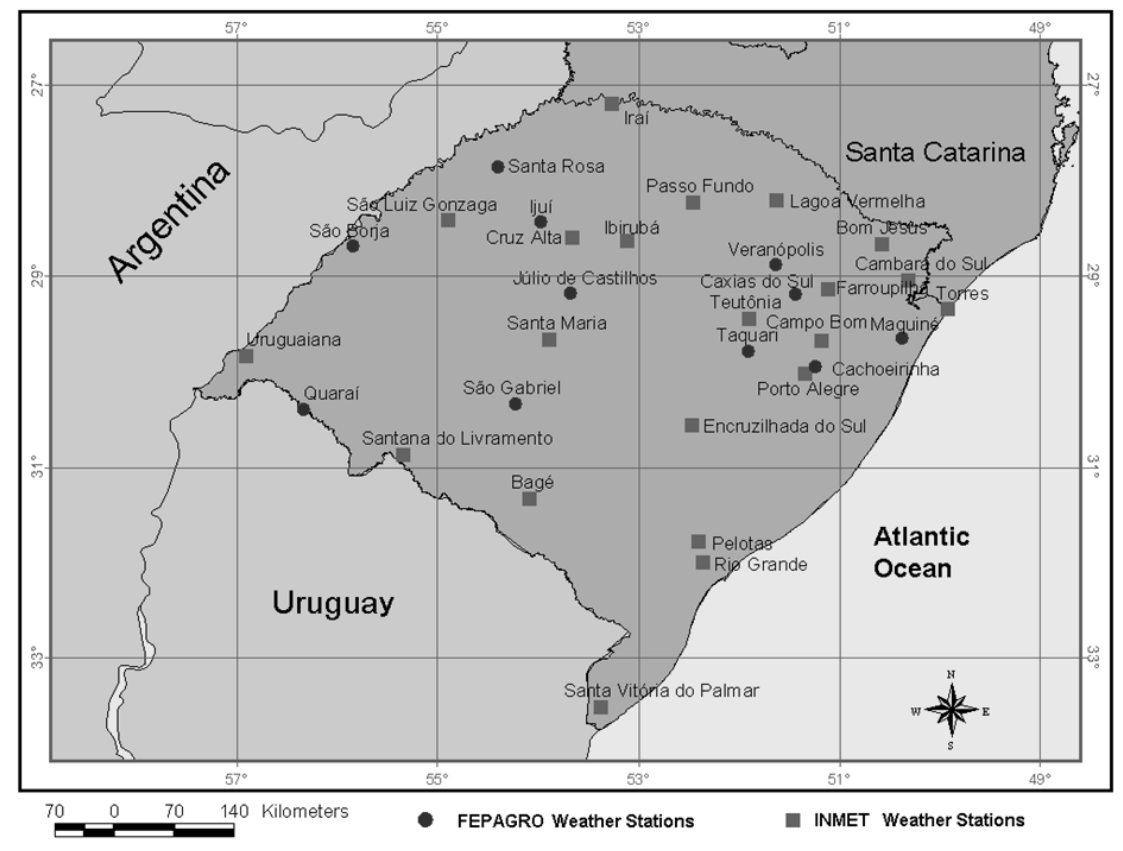

Figure 1 - Geographic distribution of the employed weather stations in RS. 
where $y$ is the precipitation of each weather station to be estimated; $x 1, x 2$ e $x 3$ are the corresponding precipitations for each month, observed at three different neighboring stations; $y m$ is the average precipitation of $y$; and $x m 1, x m 2$ and $x m 3$ are the average precipitations of three neighboring weather stations. The neighboring weather station criterion seeks to establish, not only the shortest distance among the weather stations, but also the topographic similarities with the focused weather station. The climate averages are shown in Table 2.

\section{METHODOLOGY}

\subsection{IDENTIFICATION CRITERIA}

The Forecast and Tracking of Active Convective Cells (ForTraCC) software permitted the identification of MCCs that occurred from October to December of 2003. This software was developed by Divisão de Satélites Ambientais (DSA) of Instituto Nacional de Pesquisas Espaciais (INPE). This program employs thermal infrared (IR) images from GOES-12 satellite, with a spatial resolution of $4 \mathrm{~km}\left(16 \mathrm{~km}^{2}\right)$, based on the similarities between morphologic characteristics (pattern recognition) and the superposition of convective systems, from successive imagery (Machado et al., 1998).

ForTraCC employs CTT thresholds of $235 \mathrm{~K}\left(-38^{\circ} \mathrm{C}\right)$ to define the convective cell centers and also $250 \mathrm{~K}\left(-23^{\circ} \mathrm{C}\right)$ for early detection of the systems. It should be noted that for this research, the DSA-INPE team was asked to reprocess the ForTraCC application for the study period, altering the temperature thresholds, being changed from $235 \mathrm{~K}\left(-38^{\circ} \mathrm{C}\right)$ to $241 \mathrm{~K}\left(-32^{\circ} \mathrm{C}\right)$ (warm limit) and from $210 \mathrm{~K}\left(-63^{\circ} \mathrm{C}\right)$ to $221 \mathrm{~K}$ $\left(-52^{\circ} \mathrm{C}\right)$ (cold limit). Based on these changes, it was possible to detect the convective systems with MCC characteristics, strictly following the MCC criteria given by Maddox (1980). Initially, these cloud top temperature parameters $\left(-32^{\circ} \mathrm{C}\right.$ and $-52^{\circ} \mathrm{C}$ ) were proposed by Scofield and Oliver (1977), and came from satellite image estimated precipitation data, where the $-32^{\circ} \mathrm{C}$ threshold corresponds to medium height cloudiness (approximately $6.000 \mathrm{~m}$ ). Although, this limit marks the beginning of the precipitation accumulation, it does not guarantee the determination of active precipitation areas. Conversely, the $-52^{\circ} \mathrm{C}$ limit assures that the system is active, and that there is precipitation on the surface. Also, according to Scofield and Oliver (1977), the precipitation data gathered at the

Table 1 - Location and altitude of the employed weather stations.

\begin{tabular}{|c|c|c|c|c|c|}
\hline $\mathrm{N}^{\circ}$ & Municipality & Institution & $\begin{array}{c}\text { Latitude } \\
\text { (decimal) }\end{array}$ & $\begin{array}{l}\text { Longitude } \\
\text { (decimal) }\end{array}$ & $\begin{array}{c}\text { Altitude } \\
\text { (m) }\end{array}$ \\
\hline 1 & Bagé & INMET & -31.33 & -54.11 & 216 \\
\hline 2 & Bom Jesus & INMET & -28.67 & -50.42 & 1047 \\
\hline 3 & Cachoeirinha & FEPAGRO & -29.95 & -51.12 & 5 \\
\hline 4 & Cambará do Sul & INMET & -29.05 & -50.14 & 1031 \\
\hline 5 & Campo Bom & INMET & -29.68 & -51.05 & 26 \\
\hline 6 & Caxias do Sul & INMET & -29.14 & -50.99 & 760 \\
\hline 7 & Cruz Alta & INMET & -28.60 & -53.67 & 473 \\
\hline 8 & Encruzilhada do Sul & INMET & -30.55 & -52.41 & 427 \\
\hline 9 & Farroupilha & FEPAGRO & -29.20 & -51.33 & 680 \\
\hline 10 & Ibirubá & INMET & -28.63 & -53.09 & 395 \\
\hline 11 & Iiuí & FEPAGRO & -28.44 & -54.00 & 448 \\
\hline 12 & Iraí & INMET & -27.19 & -53.25 & 227 \\
\hline 13 & Júlio de Castilhos & FEPAGRO & -29.18 & -53.69 & 514 \\
\hline 14 & Lagoa Vermelha & INMET & -28.21 & -51.53 & 807 \\
\hline 15 & Maquiné & FEPAGRO & -29.66 & -50.21 & 32 \\
\hline 16 & Passo Fundo & INMET & -28.23 & -52.40 & 709 \\
\hline 17 & Pelotas & INMET & -31.77 & -52.34 & 7 \\
\hline 18 & Porto Alegre & INMET & -30.03 & -51.23 & 10 \\
\hline 19 & Quaraí & FEPAGRO & -30.39 & -56.48 & 100 \\
\hline 20 & Rio Grande & INMET & -32.00 & -52.30 & 2 \\
\hline 21 & Santa Maria & INMET & -29.67 & -53.91 & 138 \\
\hline 22 & Santa Rosa & FEPAGRO & -27.86 & -54.44 & 273 \\
\hline 23 & Santa Vitória do Palmar & INMET & -33.52 & -53.37 & 5 \\
\hline 24 & Santana do Livramento & INMET & -30.87 & -55.43 & 210 \\
\hline 25 & São Boria & FEPAGRO & -28.69 & -55.96 & 99 \\
\hline 26 & São Gabriel & FEPAGRO & -30.34 & -54.26 & 109 \\
\hline 27 & São Luiz Gonzaga & INMET & -28.41 & -54.96 & 251 \\
\hline 28 & Taquari & FEPAGRO & -29.79 & -51.83 & 76 \\
\hline 29 & Torres & INMET & -29.34 & -49.73 & 43 \\
\hline 30 & Uruguaiana & INMET & -29.84 & -57.08 & 74 \\
\hline 31 & Veranópolis & FEPAGRO & -28.89 & -51.54 & 705 \\
\hline
\end{tabular}


pertaining weather stations (where the cloud top threshold was $-52^{\circ} \mathrm{C}$ ) almost always agreed with these criteria. It is important to state that precipitation related to higher thresholds (warmer cloud tops) may also occur.

According to Macedo et al. (2004), the identification method of a system in time ( $t$ and $t+\Delta t)$ is obtained by employing the maximum system area superposition criteria of successive images. Convective system persistence must have a minimum number of pixels to be considered the same event (150 pixels, corresponding to approximately $2,400 \mathrm{~km}^{2}$ ) for $\Delta \mathrm{t}=30$ minute. If the superposed image shows a smaller area than this, then the system is not considered the same as that shown in the preceding time.

ForTraCC (Macedo et al., 2004) was employed to identify MCC events, after being adapted to convective systems with cloud top temperature thresholds $\left(-32^{\circ}\right.$ and $\left.-52^{\circ} \mathrm{C}\right)$, defined by Maddox (1980). The DSA provided the meteorological system diagnostics text file for the period. This work only used the ForTraCC fields (data) pertaining to MCC event related parameters. These fields and their respective descriptions are offered on Table 3.

According to Macedo et al. (2004), the respective eccentricity is based on ratio between the axes of convective systems, and calculated by Equations 2.1 or 2.2:

$$
\begin{aligned}
\mathrm{e} & =\left|\frac{x x(\max )-x x(\min )}{y y(\max )-y y(\min )}\right| \\
\mathrm{e} & =\left|\frac{y y(\max )-y y(\min )}{x x(\max )-x x(\min )}\right|
\end{aligned}
$$

or

where $x x$ and $y y$ represent the longitudinal and latitudinal axes, minimum and maximum of the convective system (minor and major axes of the ellipse). The values for the eccentricity

\begin{tabular}{|c|c|c|c|c|c|c|c|c|c|c|c|c|c|c|}
\hline $\mathrm{N}$ & Weat & Jan & Feb & Mar & Apr & May & Jun & Jul & Aug & Sep & Oct & Nov & Dec & 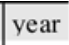 \\
\hline . & Bagé & 131 & 142 & 100 & 143 & 129 & 112 & 136 & 95 & 107 & 113 & 112 & 95 & 1415 \\
\hline 2 & Bom Jesus & 67 & 56 & 15 & 14 & 09 & 26 & 150 & 155 & 141 & 48 & 119 & 144 & 1645 \\
\hline 3 & Cachoeirinh & & 121 & 87 & 8 & 96 & 52 & 138 & 126 & 123 & 17 & 112 & 105 & 1404 \\
\hline 4 & Camb & 5 & 97 & 9 & 18 & 118 & 8 & 55 & 50 & 154 & 63 & 138 & 160 & 1774 \\
\hline 5 & Campo Bom & 139 & 124 & 11 & 38 & 114 & 164 & 164 & 147 & 145 & 162 & 130 & 121 & 1658 \\
\hline 6 & Caxi: & 3 & 2 & 2 & 6 & 17 & 52 & 64 & 61 & 60 & 60 & 130 & 146 & 1743 \\
\hline 7 & Cruz Alta & 19 & 143 & 121 & 146 & 133 & 154 & 144 & 136 & 164 & 155 & 140 & 124 & 1708 \\
\hline 8 & Encruzilhada & 119 & 120 & 5 & 17 & 121 & 156 & 142 & 127 & 134 & 15 & 111 & 102 & 1477 \\
\hline 9 & Farroupilha & 140 & 130 & 112 & 125 & 109 & 155 & 162 & 149 & 159 & 61 & 35 & 133 & 1668 \\
\hline 10 & Ibirubá & 7 & 155 & 121 & 157 & 140 & 155 & 158 & 144 & 161 & 89 & 170 & 142 & 1849 \\
\hline 11 & Ijuí & 143 & 146 & 116 & 144 & 141 & 159 & 134 & 136 & 162 & 173 & 145 & 130 & 1730 \\
\hline 12 & Iraí & 170 & 190 & 136 & 152 & 170 & 164 & 148 & 159 & 165 & 214 & 156 & 153 & 1977 \\
\hline 13 & Júlio & 130 & 137 & 123 & 124 & 124 & 150 & 149 & 134 & 144 & 158 & 132 & 114 & 1619 \\
\hline 14 & Lagoa Vermelha & 169 & 166 & 123 & 114 & 139 & 126 & 150 & 166 & 170 & 181 & 124 & 148 & 1774 \\
\hline 15 & Maquiné & & 198 & 163 & 103 & 102 & 124 & 119 & 136 & 137 & 133 & 120 & 162 & 168 \\
\hline 16 & Passo Fur & 162 & 152 & 123 & 128 & 146 & 144 & 166 & 157 & 176 & 190 & 157 & 153 & 1853 \\
\hline 7 & Pelota: & & 16 & 96 & & 98 & 10 & & 101 & 126 & & 103 & 103 & 1365 \\
\hline 18 & Porto & 1 & 111 & 102 & 110 & 106 & 145 & 146 & 134 & 130 & 115 & 110 & 109 & 1426 \\
\hline 19 & Quaraí & & 162 & 142 & 166 & 134 & & & & & 137 & 123 & 122 & 1514 \\
\hline 20 & Rio Gra & 12 & 119 & 93 & 01 & 90 & 0 & 147 & 126 & 129 & 05 & $9 ?$ & 77 & 1277 \\
\hline 1 & Santa I & & 12 & & & 116 & 139 & 149 & 121 & 138 & 44 & 127 & 106 & 1597 \\
\hline 22 & Santa Rosa & 1 & 149 & 125 & 160 & 153 & 166 & 121 & 127 & 155 & 197 & 143 & 131 & 1778 \\
\hline 23 & Santa Vitória & 108 & 140 & 94 & 97 & 99 & 105 & 139 & 102 & 104 & 88 & 94 & 87 & 1256 \\
\hline 24 & Santana do Livramento & 144 & 149 & 115 & 144 & 128 & 108 & 134 & 96 & 130 & 136 & 118 & 108 & 1511 \\
\hline 25 & São Boria & 151 & 135 & 158 & 189 & 135 & 121 & 94 & 90 & 124 & 156 & 142 & 127 & 1623 \\
\hline 26 & São Gabriel & 119 & 127 & 114 & 139 & 118 & 128 & 134 & 90 & 128 & 120 & 111 & 88 & 1416 \\
\hline 27 & São Luiz & & 159 & 167 & 200 & 163 & 175 & 151 & 140 & 162 & 193 & 158 & 154 & 1987 \\
\hline 28 & Taquari & 138 & 127 & 110 & 131 & 106 & 162 & 152 & 136 & 148 & 136 & 129 & 107 & 1583 \\
\hline 29 & Torres & 150 & 160 & 146 & 108 & 102 & 108 & 109 & 147 & 130 & 133 & 117 & 121 & 1529 \\
\hline 30 & Uruguaiana & 148 & 158 & 141 & 168 & 129 & 90 & 78 & 69 & 117 & 128 & 108 & 98 & 1432 \\
\hline 31 & Veranópolis & 14 & 140 & 99 & 120 & 120 & 133 & 149 & 144 & 163 & 152 & 140 & 139 & 1647 \\
\hline & Average & 144 & 147 & 121 & 134 & 123 & 136 & 139 & 128 & 142 & 147 & 127 & 123 & 1610 \\
\hline
\end{tabular}

Table 2 - Precipitation averages (mm) for RS (1971-2000). 
should always be positive, varying between 0 (linear system) and 1 (circular system). In this way, if the results of Equation 2.1 are negative then Equation 2.2 should be employed, and vice-versa.

TAM_A and TAM_B fields were calculated from the GOES-12 pixel size, corresponding to an area of $4 \times 4 \mathrm{~km}$ $\left(16 \mathrm{~km}^{2}\right)$. The areas of the system were calculated in $\mathrm{km}^{2}$, employing Equations 3 and 4:

TAM_A $=($ SIZE $\times 16)$

TAM B $=($ CBNUM $\times$ CBMED $\times 16)$

were SIZE defines convective system size, in pixels (cloud tops, temperature threshold of $\leq-32^{\circ} \mathrm{C}$ ); CBNUM indicates cold cloud tops $(\mathrm{Cb})$ totals that are present in the system and CBMED estimates the average $\mathrm{Cb}$ size. TAM_B (Equation 4) corresponds to an estimation of cold nucleus system size. This method estimates the size $\left(\mathrm{km}^{2}\right)$ of cold nucleus convective systems, temperature lower than $-52^{\circ} \mathrm{C}$ (Macedo et al., 2004).

GOES-12 (enhanced and IR) and Meteosat (IR) satellite imagery was used to visualize the events and localize MCC ranges for SA, Brazil (Meteosat) and southern Brazil. At this point, only the events that, at some stage of their cycle, had cloud cover area observed over RS were selected.

\subsection{Identification of MCC event associated precipitation}

Daily data were employed to identify the associated precipitation, from the 31 weather stations (Figure 1 and Table 1). The data was adjusted to a standard date/time-of-collection. Under INMET standards, the total daily precipitation from each weather station corresponds to the sum of the observations, from 18:00 UTC of the day before the observation until 12:00 UTC of the attributed day. For the FEPAGRO weather stations, the observations are read daily at 12:00 UTC and are attributed to the day before the observations were taken. To establish a standard between the different date/time-of-collection methods, the INMET dataset was adjusted to the date/time-of-collection of the day before, thus in agreement with the FEPAGRO method of collection.

After establishing the presence of cloud cover over RS, the associated precipitation was calculated using the full state data set. The date/time standard was set to the day on which rainfall was observed. Due to the time of observation, if the MCC began before 9:00 local time (LT), the precipitation was then added to the beginning of the event, the day before. The precipitation observed in the days immediately following this event was only considered if the MCC ended after 9:00 LT on any subsequent day. The spatial distribution was done using the Kriging interpolation method.

Table 3 - Selected ForTraCC fields for MCC classification

\begin{tabular}{|c|l|}
\hline Field & \\
\hline DATE & Starting date \\
\hline HOUR & Starting hour \\
\hline SYS & Identification number \\
\hline SYS_ANT & Identification of the system that originated the current one \\
\hline CLA & System classification type (new, continuation, separation, fusion) \\
\hline XLAT & Mass center latitude \\
\hline XLON & Mass center longitude \\
\hline TIME & Time interval, relating to event starting time \\
\hline SIZE & Convective system size, in pixels (cloud tops, temperature threshold of $\left.\leq-32^{\circ} \mathrm{C}\right)$ \\
\hline TMED & Average temperature (K) \\
\hline TMIN & Average minimum temperature (K) \\
\hline TMIN9 & Average temperature of the nucleus at 9 pixels $[$ neighboring analyses] $(\mathrm{K})$ \\
\hline CBNUM & Number of cold cloud tops (temperature tops $\leq-52^{\circ} \mathrm{C}$ ) \\
\hline CBMED & Size of average cold cloud top (pixels) \\
\hline ECCE & System Eccentricity \\
\hline TAM_A $\left.{ }^{*}\right)$ & System size in km ${ }^{2}$ (threshold $\leq-32^{\circ} \mathrm{C}$ ) \\
\hline TAM_B $\left.{ }^{*}\right)$ & Cold nucleus system size in $\mathrm{km}^{2}$ (threshold $\leq-52^{\circ} \mathrm{C}$ ) \\
\hline$\left(^{*}\right.$ Calculated fields. \\
\hline
\end{tabular}


Due to Daylight Savings Time (DST), beginning on October 19, 2003, it was necessary to adjust MCC event occurrence times from UTC to LT. This adjustment was necessary because ForTraCC data output corresponds to the UTC standard. Accordingly, up to October 19, three hours were subtracted from the UTC standard (Brasília UTC-3), after which, only two hours were subtracted.

\section{RESULTS AND DISCUSSION}

\subsection{Identification}

ForTraCC permitted the identification of MCC events that occurred between October and December of 2003 and that, at some instance of each MCC life cycle, was active over RS. In the three month period, $22 \mathrm{MCC}$ events were active over RS, contributing to the state's precipitation totals. Of these, seven occurred in October, seven in November and eight in December. Figure 2 shows the location of the geometric center of each identified MCC event, at the time of its maximum extent. Table 4 describes their main characteristics.

The average size of the MCCs, at their maximum extent was $1,066 \times 103 \mathrm{~km}^{2}$ (Size A: threshold of $-32^{\circ} \mathrm{C}$ ) and
$319 \times 103 \mathrm{~km}^{2}$ (Size B: threshold of $-52^{\circ} \mathrm{C}$ ). Size A class was approximately twice the size found by Velasco and Fritsch (1987), which was $500 \times 103 \mathrm{~km}^{2}$. This distinction may be associated with the differences in cloud top temperature thresholds, employed by Velasco and Fritsch (1987), $-42^{\circ} \mathrm{C}$ and $-62^{\circ} \mathrm{C}$ for Size A and B, respectively. When compared to MCC size B events obtained by Durkee and Mote (2008), this work obtained slightly larger values. Both these studies employed Maddox's criteria, although Durkee and Mote (2008) considered more events, over a much larger area.

Figures $3 \mathrm{a}, 3 \mathrm{~b}$ and $3 \mathrm{c}$ show three MCC events that occurred on October 26, November 15 and December 15, respectively. In Figure 3a, the event marked "F" extended over all of RS, SC and Uruguay, covering an area of 2,209,456 $\mathrm{km}^{2}$. Figure $3 \mathrm{~b}$ shows event " $\mathrm{J}$ " in the northwest of RS and west of SC. Figure $3 \mathrm{c}$ shows two events, one positioned over RS, event "R", and the other over northern of Argentina.

The average duration of the $22 \mathrm{MCC}$ events was $18.6 \mathrm{~h}$. The monthly averages were $13 \mathrm{~h}$ for October, $14.4 \mathrm{~h}$ for November and $27.2 \mathrm{~h}$ for December of 2003. MCC duration varied significantly from one event to another, October and November had averages of 10 to $20 \mathrm{~h}$, agreeing with the results obtained by Silva Dias (1987), while December had an average greater than $20 \mathrm{~h}$.

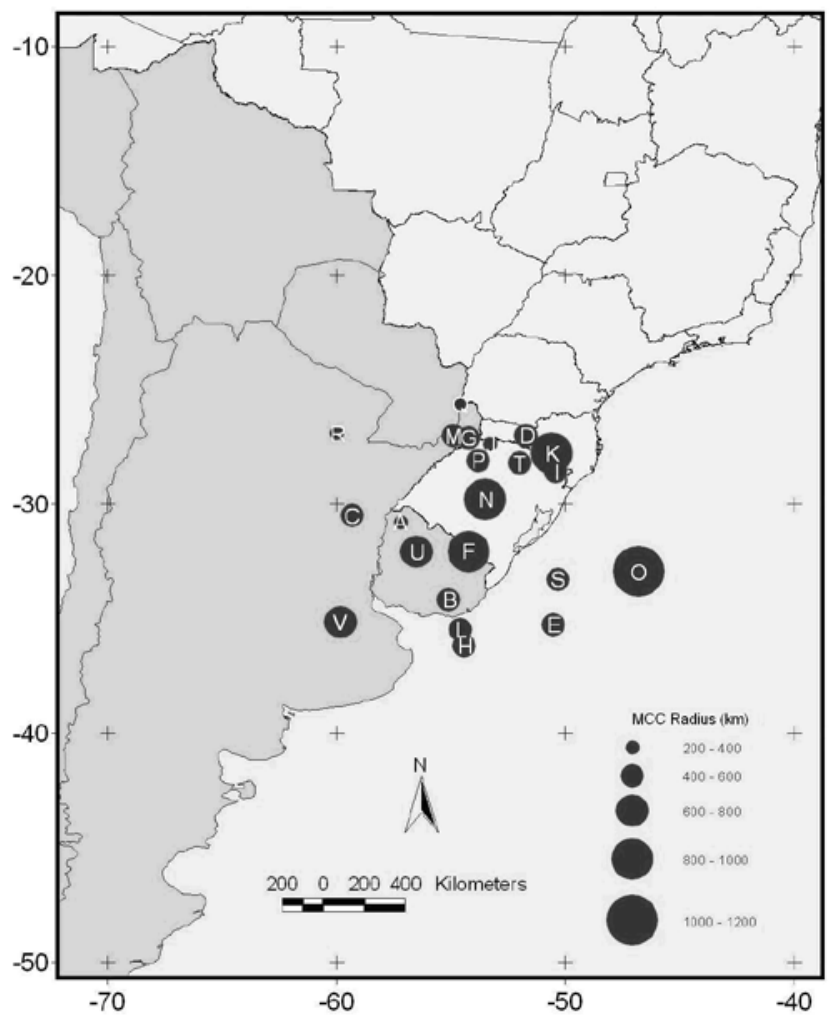

Figure 2 - Location of geometric centers of MCCs that affected RS, from October to December of 2003. The letters correspond to events listed under "MCC Code" in Table 4. 

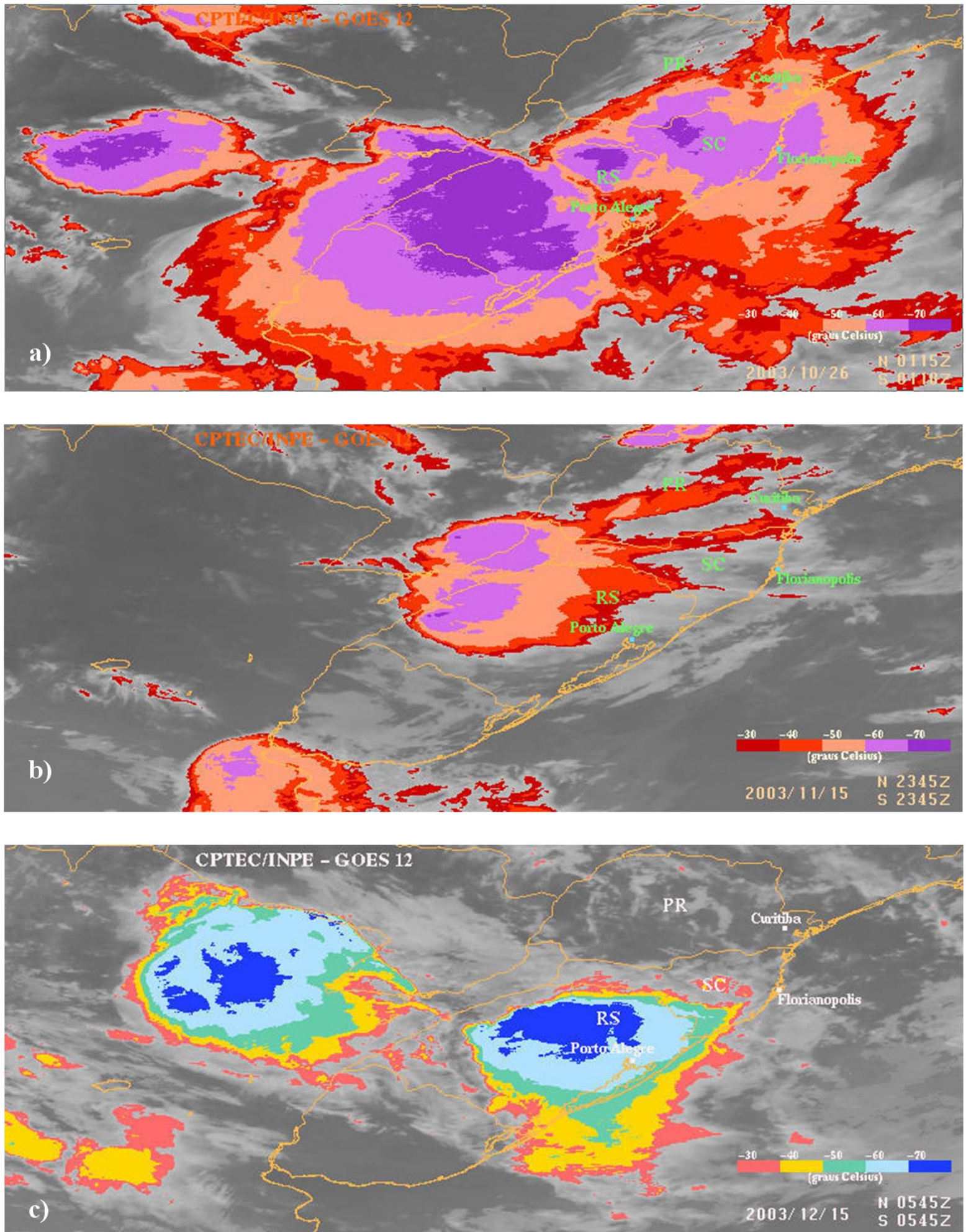

Figure 3 - GOES-12 images showing cloud top temperature enhancements of MCC events over RS on October 26 (a), November 15 (b) and December 15 (c). 
In relation to MCC event starting time, "double peak" events composed $50 \%$ of the events that began between 15:00 and 21:00 LT, and 27\% between 03:00 and 09:00 LT. These results agree with Velasco and Fritsch (1987) who found the same double peak events, revealing two different starting mechanisms for the convection: one set off by daytime heating (from 15:00 to 21:00 LT), and the other conditioned to the maximum flow of LLJ intensity, between 03:00 and 09:00 LT (Velasco and Fritsch, 1987). MCC ending time had its greatest concentration between 6:00 and 18:00 LT (64\% of the events). These results agree partially with Velasco and Fritsch (1987) and Silva Dias (1987). These studies pointed out that the ending time was between 09:00 and 12:00 LT. For this study, MCC event ending time was considered the time of dissipation or when the event split or merged with another.

An analysis of the hours when MCC maximum extent occurred revealed that $59 \%$ of MCCs reached maximum size between 18:00 and 06:00 LT, agreeing with results from Maddox (1980), Cavalcanti (1982), Maddox (1983), Velasco and Fritsch (1987). These results support the importance of the LLJ in MCC event development, due to their maximum development occurring at night when the LLJ is strongest (Virji, 1981; Cavalcanti, 1982; Guedes, 1985; Paegle, 1987; Corrêa et al., 2007).

\subsection{MCC associated precipitation}

The daily precipitation values for periods with MCCs (Table 4) compose the data set used to evaluate the MCC associated precipitation. These daily accumulations made it possible to also determine MCC event precipitation contribution (percentage) relating to monthly and three month precipitation totals (Table 5).

In the month of October 2003, the average MCC associated precipitation was $119 \mathrm{~mm}$, local values varying from $28 \mathrm{~mm}$ (Santa Vitória do Palmar) to $200 \mathrm{~mm}$ (Uruguaiana). In more than two thirds of these stations $(68 \%)$, MCC related rainfall was more than $100 \mathrm{~mm}$. MCC related precipitation, alone, was above the normals in 11 localities $(35 \%$ of the weather stations). In relation to the total precipitation for the period, the MCC contribution was $64 \%$ of the state's total precipitation. This contribution varied from $26 \%$ in Ijuí to $81 \%$ in Uruguaiana.

November showed the smallest MCC related precipitation value $(90 \mathrm{~mm})$. The associated precipitation varied from $11 \mathrm{~mm}$ (Torres) to $176 \mathrm{~mm}$ (Santa Vitória do Palmar). At five weather stations, MCC precipitation surpassed the expected normal. Despite having the smallest average precipitation, November registered the largest contribution by MCCs (65\%). The contribution of MCCs to the total precipitation varied from $21 \%$ (Torres) to $96 \%$ (Santa Vitória do Palmar).
December had the highest average precipitation from MCCs $(152 \mathrm{~mm})$ for the state as a whole, while individual stations had between $9 \mathrm{~mm}$ (Rio Grande) and $324 \mathrm{~mm}$ (Júlio de Castilhos). December had the greatest range in MCC precipitation. In 20 municipalities ( $65 \%$ of the weather stations) MCC related precipitation exceeded the expected normal. Conversely, the MCC contribution to total precipitation was the smallest among the three months $(61 \%)$. MCC contribution also had significant variations among weather stations from $14 \%$ (Pelotas) to $89 \%$ (Júlio de Castilhos).

Total accumulated precipitation for the three months was $361 \mathrm{~mm}$, averaged across all 31 weather stations. The range was from $88 \mathrm{~mm}$ in Pelotas to $585 \mathrm{~mm}$ in Santa Maria. In average, $40 \%$ of the weather stations (12 localities), MCC associated precipitation was solely responsible for surpassing the threemonth normal. The MCC rainfall contribution averaged $63 \%$, varying from $41 \%$ (Pelotas) to $82 \%$ (Santa Vitória do Palmar). These findings show that two thirds of the precipitation, between October and December, was produced from MCC events in spring 2003. Figures 4 and 5 show the spatial distribution of MCC events and the participation percentages in relation to total monthly averages.

The spatial distribution of the MCC related precipitation for the month of October showed rainfall concentrations in the northeastern, mid-eastern and far western sectors of RS. These sectors had MCC associated precipitation values of approximately $150 \mathrm{~mm}$, with some localities having greater values, such as Cachoeirinha, Cruz Alta, Veranópolis, Farroupilha, Porto Alegre, Caxias do Sul, Encruzilhada do Sul, Santa Maria, Cambará do Sul and Uruguaiana (Figure 4a).

With relation to MCC precipitation contribution for the month of October, the northeastern, mid-southern, southeastern (including the Greater Porto Alegre), and far western sectors of RS registered the largest MCC contributions, where approximately $70 \%$ of the rain was produced from MCC events in October 2003 (Figure 5a).

November MCC precipitation reached approximately $100 \mathrm{~mm}$ for a large part of state. The resulting $100 \mathrm{~mm}$ isohyet virtually divided the state in two sections (east and west), with $\leq 100 \mathrm{~mm}$ rainfall in the east and $\geq 100 \mathrm{~mm}$ in the west (Figure 4b). MCC contribution was more pronounced in the far south (Figure 5b), where Santa Vitória do Palmar had a 96\% MCC event precipitation share, the largest value for the whole study period. The far north (Iraí), mid-east (Santa Maria) and the northern coast (Maquiné) each recorded at least $80 \% \mathrm{MCC}$ contributions.

The month of December showed a clear concentration of MCC precipitation in the northern half of the state, creating a west-east $100 \mathrm{~mm}$ isohyet (Figure 4c). A great number of weather stations located in the northern half, the highlands of 
RS (Caxias do Sul, São Borja, Ijuí, Passo Fundo, Santa Maria, Ibirubá, São Luiz Gonzaga and Júlio de Castilhos), registered precipitation totals of 200 to $350 \mathrm{~mm}$. The mid-northern and northwestern sectors received $>60 \%$ of their total precipitation from MCCs in December (Figure 5c).

In Figure 4d, with the exception of the coastal plains regions and the far south, the three-month accumulated precipitation showed that MCC precipitation affected practically all of RS, reflecting both larger total precipitation and MCC event associated values of December. The MCC contribution to the total precipitation for December had the highest concentrations in the mid-northern, far western, far southern and eastern sectors of the state (Figure 5d).

\section{CONCLUSIONS}

The main goal of this study was to investigate the participation of MCCs and their associated precipitation in RS, for October, November and December of 2003. Twentytwo MCC events contributed to the precipitation totals for the period, also causing a series of damages and hazards to local populations. Almost two thirds of the registered precipitation $(63 \%)$ was associated with MCC events. December showed the largest accumulated average $(152 \mathrm{~mm})$ yet the smallest MCC contribution among the total precipitations of the three months (61\%). Alternatively, November registered the smallest average MCC precipitation $(90 \mathrm{~mm})$ and the largest MCC contribution

Table 4 - Main characteristics of MCCs that affected RS, from October to December of 2003.

\begin{tabular}{|c|c|c|c|c|c|c|c|}
\hline $\begin{array}{l}\text { Date-Hour } \\
\text { start } \\
\text { MCC (LT) }\end{array}$ & $\begin{array}{l}\text { Date-Hour } \\
\text { max. extent } \\
\text { MCC (LT) }\end{array}$ & $\begin{array}{l}\text { Date-Hour } \\
\text { end } \\
\text { MCC (LT) }\end{array}$ & $\begin{array}{c}\text { Duration } \\
\text { MCC } \\
\text { (h) }\end{array}$ & $\begin{array}{l}\text { Days of MCC } \\
\text { associated } \\
\text { precipitation }\end{array}$ & $\begin{array}{c}\text { Size A } \\
\text { at hour of max. } \\
\text { extent }\left(\mathrm{km}^{2}\right)\end{array}$ & $\begin{array}{c}\text { Size B } \\
\text { at hour of } \\
\text { max. extent } \\
\left(\mathrm{km}^{2}\right)\end{array}$ & $\begin{array}{c}\text { Eccentricity } \\
\text { at hour of } \\
\text { max. extent }\end{array}$ \\
\hline $\begin{array}{c}03 / \text { Oct } \\
04: 45\end{array}$ & $\begin{array}{l}03 / \text { Oct } \\
14: 45\end{array}$ & $\begin{array}{c}03 / \text { Oct } \\
15: 45\end{array}$ & 11.0 & 2 and $3 /$ Oct & 479,344 & 147,840 & 0.8 \\
\hline $\begin{array}{c}03 / \text { Oct } \\
16: 15\end{array}$ & $\begin{array}{l}03 / \text { Oct } \\
20: 45\end{array}$ & $\begin{array}{l}04 / \text { Oct } \\
03: 15\end{array}$ & 11.0 & $3 /$ Oct & 674,064 & 85,840 & 0.7 \\
\hline $\begin{array}{c}04 / \text { Oct } \\
04: 15\end{array}$ & $\begin{array}{l}04 / \text { Oct } \\
05: 45\end{array}$ & $\begin{array}{c}04 / \text { Oct } \\
14: 15\end{array}$ & 10.0 & 3 and $4 /$ Oct & 766,928 & 280,256 & 0.7 \\
\hline $\begin{array}{l}21 / \text { Oct } \\
01: 15\end{array}$ & $\begin{array}{l}21 / \text { Oct } \\
12: 45\end{array}$ & $\begin{array}{l}21 / \text { Oct } \\
15: 15\end{array}$ & 14.0 & 20 and $21 / \mathrm{Oct}$ & 683,536 & 143,136 & 0.8 \\
\hline $\begin{array}{l}24 / \text { Oct } \\
18: 15\end{array}$ & $\begin{array}{l}25 / \text { Oct } \\
01: 15\end{array}$ & $\begin{array}{l}25 / \text { Oct } \\
02: 45\end{array}$ & 8.5 & $24 /$ Oct & 589,840 & 256,864 & 0.9 \\
\hline $\begin{array}{c}25 / \text { Oct } \\
06: 45\end{array}$ & $\begin{array}{l}25 / \text { Oct } \\
23: 15\end{array}$ & $\begin{array}{l}26 / \text { Oct } \\
10: 45\end{array}$ & 28.0 & 24 and $25 / \mathrm{Oct}$ & $2,209,456$ & $1,063,216$ & 1.0 \\
\hline $\begin{array}{c}31 / \text { Oct } \\
16: 15\end{array}$ & $\begin{array}{l}31 / \text { Oct } \\
18: 45\end{array}$ & $\begin{array}{c}01 / \text { Nov } \\
01: 15\end{array}$ & 9.0 & $31 /$ Oct & 849,472 & 177,840 & 0.8 \\
\hline $\begin{array}{c}10 / \text { Nov } \\
20: 45\end{array}$ & $\begin{array}{c}\text { 11/Nov } \\
06: 45\end{array}$ & $\begin{array}{c}11 / \text { Nov } \\
21: 15\end{array}$ & 24.5 & 10 and $11 / \mathrm{Nov}$ & $1,080,064$ & 460,032 & 0.8 \\
\hline $\begin{array}{c}12 / \text { Nov } \\
15: 45\end{array}$ & $\begin{array}{c}\text { 12/Nov } \\
20: 45\end{array}$ & $\begin{array}{l}\text { 12/Nov } \\
21: 45\end{array}$ & 6.0 & 12/Nov & 953,136 & 415,616 & 0.7 \\
\hline $\begin{array}{c}15 / \text { Nov } \\
15: 45\end{array}$ & $\begin{array}{c}15 / \text { Nov } \\
22: 15\end{array}$ & $\begin{array}{c}\text { 16/Nov } \\
00: 45\end{array}$ & 9.0 & $15 / \mathrm{Nov}$ & 342,528 & 159,312 & 0.7 \\
\hline $\begin{array}{c}16 / \text { Nov } \\
11: 15\end{array}$ & $\begin{array}{c}17 / \text { Nov } \\
12: 15\end{array}$ & $\begin{array}{c}17 / \text { Nov } \\
12: 15\end{array}$ & 25.0 & 16 and $17 / \mathrm{Nov}$ & $2,122,976$ & 732,672 & 1.0 \\
\hline $\begin{array}{c}17 / \text { Nov } \\
14: 15\end{array}$ & $\begin{array}{c}17 / \text { Nov } \\
18: 45\end{array}$ & $\begin{array}{c}17 / \text { Nov } \\
21: 45\end{array}$ & 7.5 & $17 / \mathrm{Nov}$ & $1,104,016$ & 548,000 & 0.7 \\
\hline $\begin{array}{c}25 / \text { Nov } \\
08: 45\end{array}$ & $\begin{array}{c}25 / \text { Nov } \\
14: 45\end{array}$ & $\begin{array}{c}25 / \text { Nov } \\
14: 45\end{array}$ & 6.0 & $25 / \mathrm{Nov}$ & 651,696 & 279,680 & 1.0 \\
\hline $\begin{array}{c}26 / \mathrm{Nov} \\
03: 45\end{array}$ & $\begin{array}{c}27 / \text { Nov } \\
01: 45\end{array}$ & $\begin{array}{c}27 / \text { Nov } \\
02: 45\end{array}$ & 23.0 & 25 and $26 / \mathrm{Nov}$ & $2,055,312$ & $1,096,048$ & 0.7 \\
\hline $\begin{array}{c}\text { 07/Dec } \\
15: 45\end{array}$ & $\begin{array}{c}\text { 09/Dec } \\
03: 45\end{array}$ & $\begin{array}{c}\text { 09/Dec } \\
06: 45\end{array}$ & 39.0 & 7 and $8 / \mathrm{Dec}$ & $3,427,360$ & 901,296 & 0.7 \\
\hline $\begin{array}{c}\text { 12/Dec } \\
20: 15\end{array}$ & $\begin{array}{c}\text { 13/Dec } \\
12: 45\end{array}$ & $\begin{array}{c}\text { 13/Dec } \\
15: 15\end{array}$ & 19.0 & 12 and 13/Dec & 654,816 & 129,600 & 0.7 \\
\hline $\begin{array}{c}\text { 14/Dec } \\
01: 45\end{array}$ & $\begin{array}{c}\text { 14/Dec } \\
03: 45\end{array}$ & $\begin{array}{c}\text { 14/Dec } \\
15: 15\end{array}$ & 13.5 & 13 and $14 / \mathrm{Dec}$ & 342,576 & 160,992 & 0.7 \\
\hline $\begin{array}{c}\text { 14/Dec } \\
17: 45\end{array}$ & $\begin{array}{c}\text { 15/Dec } \\
03: 45\end{array}$ & $\begin{array}{c}\text { 15/Dec } \\
07: 15\end{array}$ & 13.5 & 14/Dec & 330,208 & 221,936 & 0.7 \\
\hline $\begin{array}{c}\text { 14/Dec } \\
20: 15\end{array}$ & $\begin{array}{c}\text { 15/Dec } \\
09: 15\end{array}$ & $\begin{array}{c}\text { 15/Dec } \\
15: 15\end{array}$ & 19.0 & 14 and $15 / \mathrm{Dec}$ & 840,768 & 159,104 & 0.7 \\
\hline $\begin{array}{c}\text { 20/Dec } \\
09: 45\end{array}$ & $\begin{array}{c}\text { 20/Dec } \\
15: 45\end{array}$ & $\begin{array}{c}21 / \text { Dec } \\
10: 45\end{array}$ & 25.0 & 19 and 20/Dec & $1,076,864$ & 309,680 & 1.0 \\
\hline $\begin{array}{c}\text { 21/Dec } \\
08: 45\end{array}$ & $\begin{array}{c}\text { 22/Dec } \\
08: 15\end{array}$ & $\begin{array}{c}\text { 22/Dec } \\
08: 15\end{array}$ & 23.5 & 20 and $21 / \mathrm{Dec}$ & $1,362,112$ & 769,296 & 0.7 \\
\hline $\begin{array}{c}\text { 25/Dec } \\
17: 45\end{array}$ & $\begin{array}{c}27 / \mathrm{Dec} \\
02: 45\end{array}$ & $\begin{array}{c}28 / \text { Dec } \\
10: 45\end{array}$ & 65.0 & $\begin{array}{c}25,26 \text { and } \\
27 / \mathrm{Dec}\end{array}$ & $1,387,088$ & 650,880 & 0.7 \\
\hline
\end{tabular}


$(65 \%)$. October registered intermediate values $(119 \mathrm{~mm})$ for MCC associated precipitation and contribution (64\%).

The spatial distribution of the MCCs and their associated precipitation demonstrated that such events had a very significant contribution at some localities in RS. The largest accumulated percentages were found for the western, mid-northern and far southern sectors of RS, with MCCs contributing more than $60 \%$ to the precipitation totals. The prevalence of MCC events in the northern half of RS, represented by the average accumulation, reflected the high values found for December - the month with the largest accumulated precipitation totals.

Some of the main physical characteristics of MCCs described in the literature were confirmed (life cycle, starting time, maximum extension and event ending), but the results also determined that the average size of MCC events was double that found for SA by Velasco and Fritsch (1987), although these authors employed narrower temperature thresholds $\left(-42^{\circ} \mathrm{C}\right.$ and $\left.-62^{\circ} \mathrm{C}\right)$. This may have led these authors to underestimate MCC events. The present study found that MCC average size was approximately three times larger than such events studied by Maddox (1980) in the US, showing an average size of $300 \times 103 \mathrm{~km}^{2}$.

The ForTraCC application was found to be efficient at calculating the physical parameters proposed by Maddox (1980) to classify MCC events, although the present study found twice the number of MCCs in December than Climanálise (2003c), eight and four, respectively. It is important to note that the CTT criteria for this work follows Maddox (1980). This discrepancy may be related to the difference in defining the parameter of MCC event analyses. This study considers that the end of the MCC events occurs when it ceases to comply with the established size criteria (Size A and B). This could happen due to dissipation, separation or fusion with other ongoing events. This is the case for the events registered from December 12 to 15 , where this work defined four MCCs, but Climanálise (2003c) only showed one MCC on December 13.

This work only evaluated the physical characteristics identifying MCC events (Size A and B), and did not consider the

Table 5 - MCC total precipitation ( $\mathrm{mm}$ ) and contribution relating to monthly and three month precipitation totals in percentages (\%).

\begin{tabular}{|c|c|c|c|c|c|c|c|c|c|c|c|c|}
\hline \multirow[b]{2}{*}{ weat } & \multicolumn{3}{|c|}{ October $/ 2003$} & \multicolumn{3}{|c|}{ November/2003 } & \multicolumn{3}{|c|}{ December/2003 } & \multicolumn{3}{|c|}{3 month Accumulation } \\
\hline & $\begin{array}{l}\text { Total } \\
(\mathrm{mm})\end{array}$ & $\begin{array}{l}\text { MCC } \\
(\mathrm{mm})\end{array}$ & $\begin{array}{c}\text { Contrib } \\
(\%)\end{array}$ & $\begin{array}{l}\text { Total } \\
(\mathrm{mm})\end{array}$ & $\begin{array}{l}\text { MCC } \\
(\mathrm{mm})\end{array}$ & $\begin{array}{c}\text { Contrib } \\
(\%)\end{array}$ & $\begin{array}{l}\text { Total } \\
(\mathrm{mm})\end{array}$ & $\begin{array}{l}\text { MCC } \\
(\mathrm{mm})\end{array}$ & $\begin{array}{c}\text { Contrib } \\
(\%)\end{array}$ & $\begin{array}{l}\text { Total } \\
(\mathrm{mm})\end{array}$ & $\begin{array}{l}\text { MCC } \\
(\mathrm{mm})\end{array}$ & $\begin{array}{c}\text { Contrib } \\
(\%)\end{array}$ \\
\hline 1 Bagé & 187 & 117 & 63 & 193 & 124 & 64 & 107 & 77 & 72 & 487 & 318 & 65 \\
\hline 2 Bom Jesus & 219 & 147 & 67 & 122 & 49 & 40 & 330 & 162 & 49 & 671 & 357 & 53 \\
\hline 3 Cachoeirinha & 199 & 150 & 75 & 108 & 79 & 74 & 207 & 139 & 67 & 513 & 368 & 72 \\
\hline 4 Cambará do Sul & 232 & 186 & 80 & 72 & 23 & 31 & 218 & 116 & 53 & 523 & 325 & 62 \\
\hline 5 Campo Bom & 204 & 134 & 66 & 102 & 57 & 56 & 215 & 141 & 65 & 521 & 332 & 64 \\
\hline 6 Caxias do Sul & 226 & 170 & 75 & 155 & 93 & 60 & 335 & 215 & 64 & 716 & 478 & 67 \\
\hline 7 Cruz Alta & 227 & 155 & 68 & 214 & 121 & 57 & 328 & 196 & 60 & 769 & 472 & 61 \\
\hline 8 Encruzilhada do Sul & 225 & 175 & 78 & 143 & 110 & 77 & 184 & 87 & 47 & 552 & 372 & 68 \\
\hline 9 Farroupilha & 217 & 170 & 78 & 104 & 74 & 72 & 299 & 196 & 65 & 620 & 440 & 71 \\
\hline 10 Ibirubá & 219 & 133 & 61 & 187 & 107 & 57 & 395 & 245 & 62 & 801 & 485 & 61 \\
\hline $11 \mathrm{Ijui}$ & 190 & 50 & 26 & 131 & 72 & 55 & 432 & 233 & 54 & 753 & 355 & 47 \\
\hline 12 Iraí & 271 & 132 & 49 & 142 & 119 & 84 & 341 & 184 & 54 & 754 & 434 & 58 \\
\hline 13 Júlio de Castilhos & 195 & 130 & 67 & 172 & 93 & 54 & 364 & 324 & 89 & 731 & 548 & 75 \\
\hline 14 Lagoa Vermelha & 192 & 144 & 75 & 123 & 78 & 63 & 256 & 154 & 60 & 571 & 377 & 66 \\
\hline 15 Maquiné & 147 & 100 & 68 & 79 & 64 & 80 & 158 & 88 & 56 & 385 & 252 & 65 \\
\hline 16Passo Fundo & 268 & 148 & 55 & 138 & 86 & 63 & 392 & 243 & 62 & 797 & 477 & 60 \\
\hline 17 Pelotas & 58 & 39 & 68 & 81 & 38 & 47 & 75 & 11 & 14 & 213 & 88 & 41 \\
\hline 18 Porto Alegre & 236 & 170 & 72 & 92 & 60 & 65 & 185 & 105 & 57 & 512 & 336 & 66 \\
\hline 19Quaraí & 144 & 94 & 66 & 181 & 130 & 72 & 161 & 120 & 75 & 486 & 345 & 71 \\
\hline 20R io Grande & 51 & 30 & 59 & 80 & 62 & 78 & 59 & 9 & 15 & 190 & 101 & 53 \\
\hline 21 Santa Maria & 232 & 177 & 77 & 192 & 165 & 86 & 356 & 243 & 68 & 779 & 585 & 75 \\
\hline 22 Santa Rosa & 161 & 45 & 28 & 159 & 59 & 37 & 312 & 179 & 57 & 631 & 283 & 45 \\
\hline 23 Santa Vitória do Palmar & 50 & 28 & 56 & 182 & 176 & 96 & 55 & 31 & 57 & 287 & 235 & 82 \\
\hline 24Santana do Livramento & 60 & 32 & 53 & 175 & 117 & 67 & 205 & 83 & 41 & 439 & 232 & 53 \\
\hline 25 São Borja & 177 & 100 & 56 & 181 & 130 & 72 & 318 & 230 & 72 & 676 & 459 & 68 \\
\hline 26São Gabriel & 116 & 62 & 53 & 89 & 50 & 56 & 171 & 96 & 56 & 376 & 207 & 55 \\
\hline 27 São Luiz Gonzaga & 176 & 80 & 45 & 202 & 144 & 71 & 343 & 254 & 74 & 721 & 478 & 66 \\
\hline 28 Taquari & 238 & 133 & 56 & 115 & 91 & 80 & 237 & 171 & 72 & 589 & 395 & 67 \\
\hline 29 Torres & 148 & 98 & 66 & 50 & 11 & 21 & 186 & 95 & 51 & 384 & 204 & 53 \\
\hline 30 Uruguaiana & 246 & 200 & 81 & 146 & 100 & 68 & 176 & 109 & 62 & 567 & 409 & 72 \\
\hline 31 Veranópolis & 225 & 167 & 74 & 164 & 105 & 64 & 397 & 183 & 46 & 787 & 455 & 58 \\
\hline Average & 185 & 119 & 64 & 138 & 90 & 65 & 251 & 152 & 61 & 574 & 361 & 63 \\
\hline
\end{tabular}



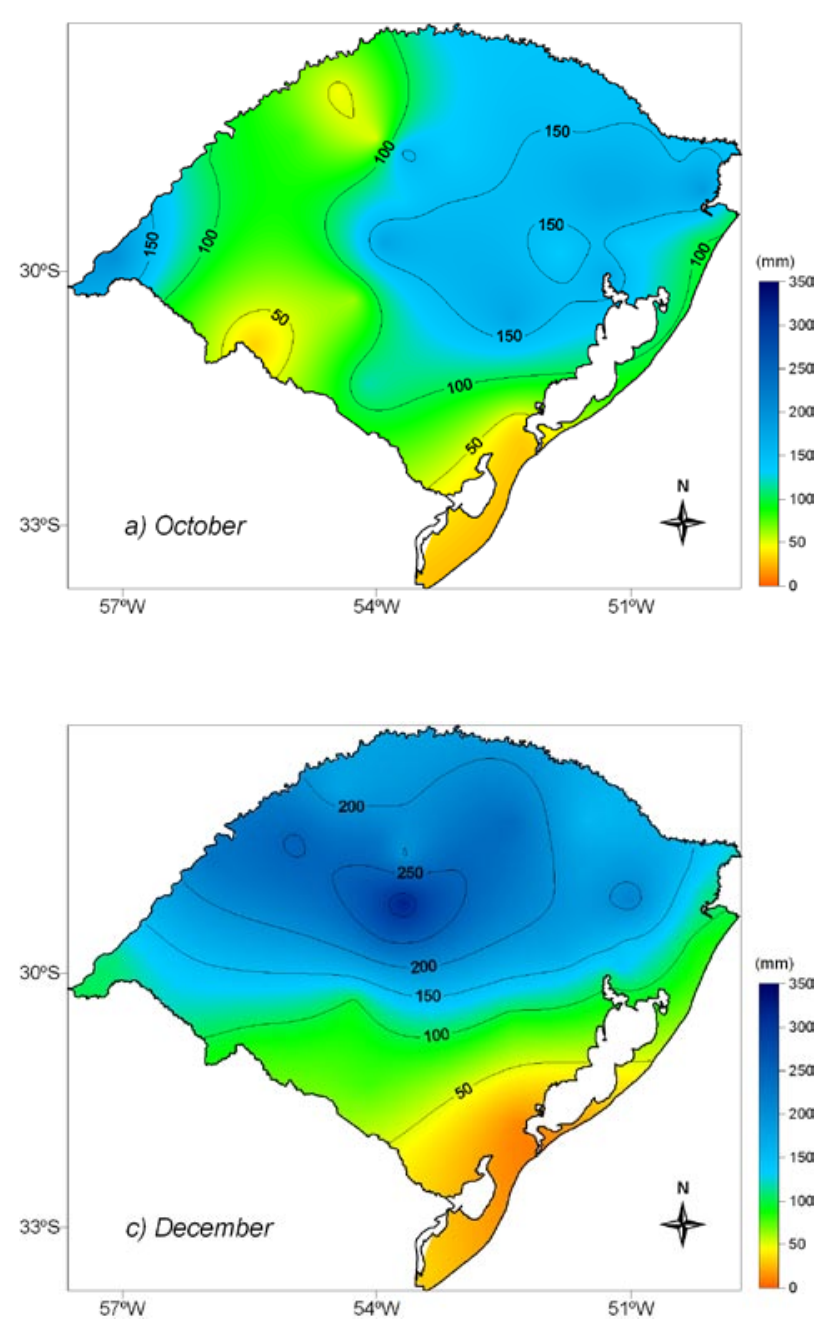
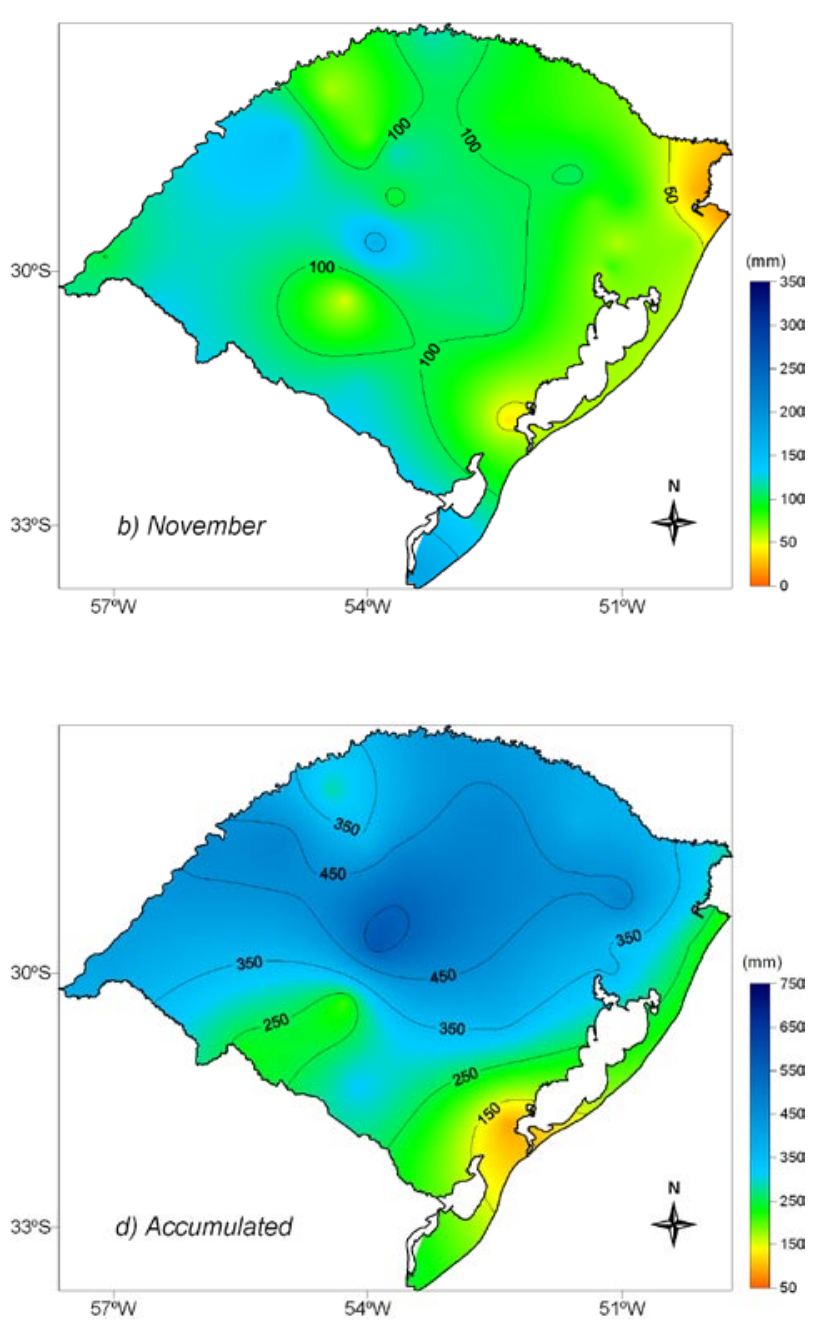

Figure 4 - MCC related precipitation (mm) for RS: October (a), November (b), December (c) and three-month accumulated values (d).

associated synoptic conditions. Although such conditions were not explicitly considered, it was observed that some of the MCCs developed under pre-frontal conditions, where the advance of a cold air mass may have acted as a valley-mountain breeze driver, triggering the convection. Therefore, the differences in results between this work and Climanálise (2003c), regarding the MCC events of December, 2003, may be linked to such atmospheric conditions.

The methodology to evaluate MCCs in RS could be improved, given the operation of a greater number of weather stations with better spatial and temporal resolution. The ideal situation would be the access of hourly observations, but few automatic weather stations, of both official observing systems in RS (INMET and FEPAGRO), operate at this resolution. Thus, the option was to use the maximum number of weather stations, allowing the best spatial coverage for the present study.

\section{ACKNOWLEDGMENTS}

We thank the team at Divisão de Satélites Ambientais (DSA) from Instituto Nacional de Pesquisas Espaciais (INPE) for all their assistance with the FORTRACC data and images. We also greatly thank Thomas Mote and the anonymous referees for their contributions to this paper.

\section{REFERENCES}

ABDOULAEV S.; STAROSTIN, A.; CASARIN, D.P. Sistemas de mesoescala de precipitações no Rio Grande do Sul. Parte 1: Descrição Geral. IX Congresso Brasileiro de Meteorologia, SBMET. Campos de Jordão. Anais...2, p. 936-940, 1996. ASHLEY, W.S.; MOTE, T.L.; DIXON, P.G.; TROTTER, S.L.; 

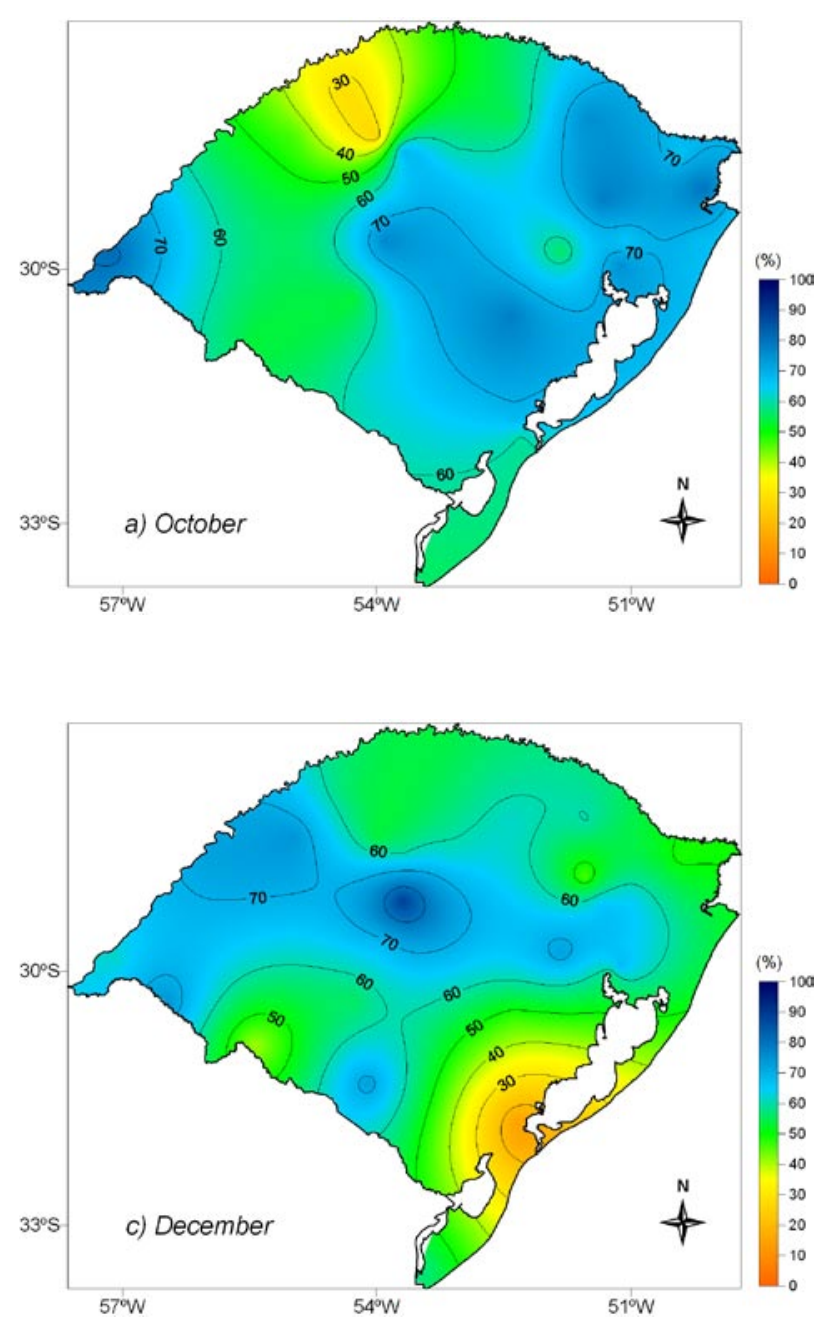
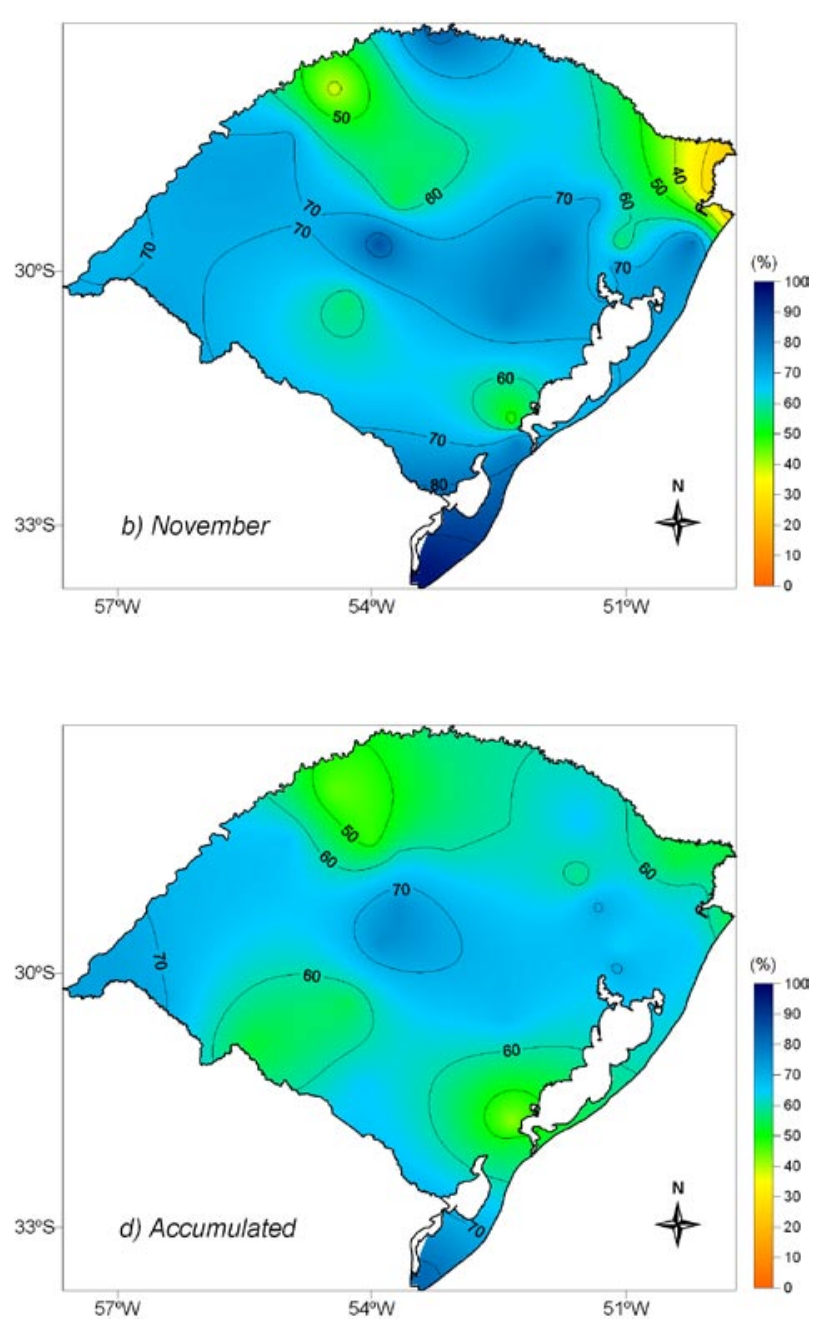

Figure 5 - MCC related precipitation contribution (\%) for RS, relative to monthly totals: October (a), November (b), December (c) and the accumulated three months (d).

POWELL, E.J.; DURKEE, J.D.; GRUNDSTEIN, A.J. Distribution of Mesoscale Convective Complex Rainfall in the United States. Mon. Wea. Rev., v.131, p.3003-3017, 2003.

BONATTI, J.P.; RAO, V.B. Moist Baroclinic Instability in the Development of North Pacific and South American Intermediate-Scale Disturbances. J. Atm. Sci., v.44, n.18, p.2657-2667, 1987.

CAVALCANTI, I. F. A. Um estudo sobre interações entre sistemas de circulação de escala sinótica e circulações locais. 1982. 133 f. Dissertação de Mestrado em Meteorologia. Instituto Nacional de Pesquisas Espaciais, São José dos Campos INPE-2494-TDL/097, 1982.

CLIMANÁLISE. Boletim de Monitoramento e Análise Climática. v.18, n.10, 2003a.

CLIMANÁLISE. Boletim de Monitoramento e Análise Climática. v.18, n.11, 2003b.
CLIMANÁLISE. Boletim de Monitoramento e Análise Climática. v.18, n.12, 2003c.

CORFIDI, S.F.; MERRITT, J.H.; FRITSCH, J.M. Predicting the Movement of Mesoscale Convective Complexes. Weather and Forecasting, v.11, p.41-46, 1996.

CORRÊA, C.S; CLARKE, R.T.; SILVEIRA, A.L.L. Estudo da Ocorrência de Fluxos no Perfil Vertical do Vento na Baixa Atmosfera com Análise das Componentes Principais (ACP) e a sua Relação com a Precipitação no Rio Grande do Sul. Revista Brasileira de Meteorologia, v.22, n.1, p.121-127, 2007. COTTON, W.R.; LIN, M.S.; MCANELLY, R.L.; TREMBACK, C.J. A Composite Model of Mesoscale Convective Complexes. Mon. Wea. Rev., v.117, p.765-783, 1989.

DURKEE, J.D.; MOTE, T.L. A Climatology of Warm-Season Mesoscale Convective Complex and Subtropical South America. Int. J. Clim. (submitted), 2008. 
DUQUIA, C.G.; SILVA DIAS, M.A.F. Complexo convectivo de mesoescala: um estudo de caso para o oeste do Rio Grande do Sul. In: VIII Congresso Brasileiro de Meteorologia, SBMET, Anais... 2, p.610-612, 1994.

FIGUEIREDO, J.C.; SCOLAR, J. Estudo da trajetória dos sistemas convectivos de mesoescala na América do Sul. In: VII Congresso Latino-Americano e Iberico de Meteorologia, Buenos Aires, Anais..., p.165-166, 1996.

FRITSCH, J.M.; KANE, R.J.; CHELIUS, C.R. The Contribution of Mesoscale convective Weather Systems to the WarmSeason Precipitation in the United States. J. Clim. Appl. Meteorol., v.25, p.1333-1345, 1986.

GUEDES, R.L. Condições de grande escala associadas a sistemas convectivos de mesoescala sobre a região central da América do Sul. Dissertação de Mestrado. São Paulo, SP, IAG/USP, 89 p., 1985.

GUEDES, R.L.; SILVA DIAS, M.A.F. Estudo de tempestades severas associadas com o jato subtropical na América do Sul. In: III Congresso Brasileiro de Meteorologia, SBMET. Belo Horizonte, MG, 3-7 Dezembro, Anais..., v.1, p.289296, 1984

GUEDES, R.L.; MACHADO, L.A.T.; SILVEIRA, J.M.B.; ALVES, M.A.S.; WALTZ, R.C. Trajetórias dos sistemas convectivos sobre o continente americano. VIII Congresso Brasileiro de Meteorologia, SBMET, Anais... 2, p.77-80, 1994.

LAING, A.G.; FRITSCH, J.M. Mesoscale Convective Complexes over the Indian Monsoon Region. J. Clim. v.6, p.911-919, 1993.

LAING, A.G.; FRITSCH, J.M.; NEGRI, A.J. Contribution of Mesoscale Convective Complexes to Rainfall in Sahelian Africa: Estimates from Geostationary Infrared and Passive Microwave Data. J. Appl. Meteorol., v.38, p.957-964, 1999.

MACEDO, S.R.; VILA, D.; MACHADO, L.A. FORTRACC - Previsão a curto prazo e evolução dos sistemas convectivos: FORTRACC V1.1 - Guia de Usuário. [São Paulo]: INPE/ CPTEC, 2004. Disponível em: <http://moara.cptec.inpe. br/pdf/FORTRACC.pdf $>$. Acesso em: 01/07/2006.

MACHADO, L.A.T.; GUEDES, R.L.; SILVEIRA, J.M.B.; WALTZ, R.C; ALVES, M.A.S. Ciclo de vida de sistemas convectivos. In: VIII Congresso Brasileiro de Meteorologia, SBMET, Anais... 2, p.323-326, 1994.

MACHADO, L.A.T.; ROSSOW, W.B.; GUEDES, R.L.; WALKER, A.W. Life Cycle Variations of Mesoscale Convective Systems over the Americas. Mon. Wea. Rev., v.126, p.1630-1654, 1998.

MADDOX, R.A. Mesoscale Convective Complexes. Bul. Amer. Meteorol. Soc., v.61, n.11, p.1374-1387, 1980.

MADDOX, R.A. Large-Scale Meteorological Conditions
Associated with Midlatitude, Mesoscale Convective Complexes. Mon. Wea. Rev., v.111, p.1475-1493, 1983.

MARENGO, J.A.; SOARES, W.R.; SAULO, C.; NICOLINI, M. Climatology of the Low-Level Jet East of the Andes as Derived from the NCEP-NCAR Reanalyses: Characteristics and Temporal Variability. J. Clim., v.17, n.12, p.2261-2280, 2004.

MCANELLY, R.L.; COTTON, W.R. The Precipitation Life Cycle of Mesoscale Convective Complexes over the Central United States. Mon. Wea. Rev., v.117, p.784-808, 1989.

MILlER, D.; FRITSCH, J.M. Mesoscale Convective Complexes in the Western Pacific Region. Mon. Wea. Rev., v.119, p.2978-2992, 1991.

NOGUÉS-PAEGLE, J.; BERBERY, E.H. Low-level Jets over the Americas. Exchanges - Selected Research Papers. N ${ }^{\circ}$ 16, Jun/2000.

PAEGLE, J. Interactions between convective and largescale motions over Amazonia. In: The geophysiology of Amazonia: Vegetation and Climate Interactions. R. Dickerson ed., Wiley Intersciences, p.347-390, 1987.

ROCHA, R.P. Simulação numérica de sistema de mesoescala sobre a América do Sul. Dissertação de Mestrado. São Paulo. IAG/USP, 1992.

SATYAMURTY, P.; NOBRE, C.A.; SILVA DIAS, P.L. South America. In: Meteorology of the Southern Hemisphere. Boston: A.M.S., v.27. p.119-139, 1998.

SCAGLIONI, T.P.; GOMES, R.G. Formação e Desenvolvimento de três sistemas de nuvens no Sul da América do Sul. In: IX Congreso Argentino de Meteorologia, Buenos Aires. Tiempo, Clima, Agua y Dessarrollo Sostenible, Anais..., 2005.

SCOFIELD, R.A.; OLIVER, V.J. A scheme for estimating convective rainfall from satellite imagey. NOAA Technical Memo. NESS 86, Washington D.C. 47 p., 1977.

SCOLAR, J.; FIGUEIREDO, J.C. Análise das condições sinóticas associadas à formação de Complexos Convectivos de Mesoescala. In: VI Congresso Brasileiro de Meteorologia, SBMET, Anais... v.2, p.457-461, 1990.

SCOLAR, J.; SILVA DIAS, M.A.F. Linhas de instabilidade pré-frontais e sua dependência de condições sinóticas. In: II Congresso Brasileiro de Meteorologia, SBMET, Anais... v.4, p.88-102, 1982.

SELUCHI, M.E.; MARENGO, J.A. Tropical-midlatitude Exchange of Air Masses During Summer and Winter in south America: Climatic Aspects and Examples of Intense Events. Int. J. Climatol., v.20, p.1167-1190, 2000.

SEVERO, D.L.; GAN, M.A. Anomalias de precipitação na região sul do Brasil: resultados preliminares. In: XII Congresso Brasileiro de Meteorologia. Anais... SBMET, 2004. 
SILVA DIAS, M.A.F. Sistemas de Mesoescala e Previsão de Tempo à Curto Prazo. Revista Brasileira de Meteorologia. v.2, p.133-150, 1987.

SILVA DIAS, M.A.F. Complexos Convectivos de Mesoescala sobre a Região Sul do Brasil. Revista Climanálise (Edição comemorativa de 10 Anos), 1996. Available at $<$ http://tucupi. cptec.inpe.br/products/climanalise/cliesp $10 \mathrm{a} / \mathrm{mcc}$ _cli. html $>$. Accessed in 05/12/2006.

TORRES, J.C.; NICOLINI, M. A composite mesoscale convective systems over southern South America and its relationship to low-level jet events. VAMOS/CLIVAR/ WRCP. Conference on South American low-level jet. Santa Cruz de la Sierra, Bolívia, Fevereiro/2002.
TUBELIS, A.; NASCIMENTO, F.J.L. Meteorologia Descritiva: fundamentos e aplicações brasileiras. São Paulo: Nobel. 374 p., 1980.

TUCKER, D.F.; ZENTMIRE, K.S. On the Forecasting of Orogenic Mesoscale Convective Complexes. Weather and Forecasting. v.14. p.1017-1022, 1999.

VELASCO, I.; FRITSCH, J.M. Mesoscale Convective Complexes in the Americas. J. Geophys. Res., v.92, n.D8, p.9591-9613, 1987.

VIRJI, H. A Preliminary Study of Summertime Tropospheric Circulation Patterns over South America Estimated from Cloud Winds. Mon. Wea. Rev., v.109, p.599-610, 1981. 